\title{
Unravelling efficient applications of agriculturally important microor- ganisms for alleviation of induced inter-cellular oxidative stress in crops
}

\author{
Chetan KESWANI ${ }^{1,2}$, Hagera DILNASHIN ${ }^{1}$, Hareram BIRLA, S.P. SINGH ${ }^{1}$
}

Unravelling efficient applications of agriculturally important microorganisms for alleviation of induced inter-cellular oxidative stress in crops

Abstract: Abiotic stresses like high temperature, cold, freezing, drought, salinity, flooding or oxidizing agents cause significant loss in the crop yield and quality. Abiotic stresses cause reactive oxygen species (ROS) production such as singlet oxygen $\left({ }^{1} \mathrm{O}_{2}\right)$, hydrogen peroxide $\left(\mathrm{H}_{2} \mathrm{O}_{2}\right)$, superoxide radical $\left(\mathrm{O}_{2}{ }^{-}\right)$, hydroxyl radical $\left(\mathrm{OH}^{-}\right)$, etc., that leads to a significant reduction of crop yield. A major source of ROS production in plants through aerobic metabolism is chloroplast, mitochondria, and peroxisome. The tripartite interactions involving Trichoderma- Phytopathogen-Host have received less attention in contrast to the plant-antagonist, plant-pathogen or pathogen-antagonist interactions. This article explores the possibilities of employing thermotolerant strains of agriculturally important microorganisms (AIMs) for alleviating the oxidative stress induced due heat stress in crops by modulating oxidative and defense network of the host.

Key words: heat stress; ROS; AIMs; abiotic stress; crop protection
Received February 12, 2019; accepted September 12, 2019. Delo je prispelo 12. februarja 2019, sprejeto 12. septembra 2019.

Pojasnitev učinkovite uporabe kmetijsko pomembnih mikroorganizmov pri blaženju oksidacijskega stresa v celicah kmetijskih rastlin

Izvleček: Abiotski stresorji kot so visoke temperature, mraz, zmrzovanje, suša, slanost, poplave ali oksidacijska sredstva povzročajo znantne izgube pridelka in kakovosti kmetijskih rastlin. Abiotski stresorji povzročajo nastanek reaktivnih zvrsti kisika (ROS) kot so singletni kisik $\left({ }^{1} \mathrm{O}_{2}\right)$, vodikov peroksid $\left(\mathrm{H}_{2} \mathrm{O}_{2}\right)$, superoksidni radikal $\left(\mathrm{O}_{2}^{--}\right)$, hidroksilni radikal $\left(\mathrm{OH}^{-}\right)$, itd., kar vodi $\mathrm{k}$ znantnemu zmanjšanju pridelka kmetijskih rastlin. Glavni vir nastanka ROS v rastlinah je aerobna presnova $\mathrm{v}$ kloroplastih, mitohondrijih in peroksisomih. Tripartitne interakcije, ki vključujejo glivo iz rodu Trichodermafitopatogena in gostitelja so bile deležne manj pozornosti v nasprotju s sistemi kot so rastlina- antagonist, rastlina-patogen ali interakcije pathogen - antagonist. V članku so prikazane možnosti uporabe termotolerantnih sevov kmetijsko pomembnih mikroorganismov (AIMs) za blaženje oksidacijskega stresa, ki ga v kmetijskih rastlinah sproži vročinski stres z modulacijo oksidativnega in obrambnega odziva gostitelja.

Ključne besede: vročinski stres; ROS; AIMs; abiotski stres; zaščita kmetijskih rastlin

1 Department of Biochemistry, Institute of Science, Banaras Hindu University, Varanasi, India

2 Corresponding author, e-mail: chetan.keswani4@bhu.ac.in 


\section{ABIOTIC STRESSES IN PLANTS}

Plants are frequently exposed to a plethora of unfavorable environmental conditions, thereby posing a serious threat to sustainable crop production (Bhatnagar-Mathur et al., 2008). In continuously changing environment, plants are constantly challenged by various abiotic stresses (drought, salinity, temperature extremes, heavy metal toxicity, high-light intensity, nutrient deficiency, UV-B radiation, ozone, etc.) which cause considerable losses in the yield and quality of a crop (NAAS, 2017; Hasanuzzaman et al., 2012). Abiotic stress is best defined as any aspect exerted by the environment on the optimal functioning of an organism. Abiotic stresses like heat, cold, freezing, drought salinity, flooding or oxidizing agents usually cause protein dysfunction (NAAS, 2013; Wang et al., 2004).

A number of abnormal environmental factors are collectively termed as abiotic stresses. Abiotic stresses alter plant metabolism leading to harmful effects on growth, development, and productivity. If the stress becomes very high and continues for an extended period, it may lead to an unbearable metabolic load on cells, reducing growth, and in severe cases, resulting in plant death (Keswani, 2015). However, plant stress may vary depending on the types of stress factors and on the prevailing period. In nature, plants may not be completely free from abiotic stresses. They are expected to experience some degree of stress by different factors (Keswani, 2019). Some environmental factors, such as air temperature, can become stressful in just a few minutes; others, such as soil water content, may take few days to weeks, and factors such as soil mineral deficiencies/overload may take months to become stressful (Taiz \& Zeiger, 2006). These stresses are associated with the production of ROS, capable of inducing cellular damage by proteins degradation, enzymes inactivation and alterations in the gene expression (Kumar et al., 2017; Choudhury et al., 2013). Abiotic stresses remain the greatest constraint to worldwide crop production. It has been estimated that more than $50 \%$ of yield reduction is the direct result of abiotic stresses (Keswani, 2015; Acquaah, 2007; Camejo et al., 2005). Abiotic stress leads to a series of morphological, physiological, biochemical and molecular changes that adversely affect plant growth and productivity (Mishra et al., 2015; Wang et al., 2001).

\section{GLOBAL WARMING}

Global warming is a gradual increase in the global atmospheric temperature of the Earth, usually caused by the greenhouse effect due to higher levels of $\mathrm{CO}_{2}$,
CFCs and other pollutants (Chitara et al., 2017; Broecker, 1975). Warmer temperatures may make many crops grow more quickly, but warmer temperatures could also reduce yields. Crops tend to grow faster in warmer conditions. However, for some crops (such as grains), faster growth reduces the amount of time that seeds have to grow and mature. Extreme temperature and rainfall can inhibit crops growth (Karl et al., 2009). It was reported that for every $1{ }^{\circ} \mathrm{C}$ rise in temperature the decline in rice yield would be about $6 \%$ (Saseendran et al., 2000).

\section{CLIMATE CHANGE AND ITS IMPACT ON AGRICULTURE}

Agriculture depends on the favorable climate, hence is among the sectors of the global economy where most concern currently lies in the context of climate change in order to maintain global food security (Mertz et al., 2009). The Inter-Governmental Panel on Climate Change (IPCC), fourth assessment report (Field et al., 2014) stated that human-induced climate change is real, and identified agriculture as a critical sector. Climate change is likely to affect crop productivity directly through changes in crop environment and indirectly through the prevalence of agriculture insect and pest, associated impact on soil fertility and biological function and agriculture biodiversity can also be observed (Lobell \& Burke, 2010).

\section{HIGH TEMPERATURE STRESS}

Heat stress is often defined as a rise in temperature beyond a threshold level for a period of time sufficient to cause irreversible damage to plant growth and development. A transient temperature elevation, typically 10 $15^{\circ} \mathrm{C}$ above ambient, is generally considered to be a heat shock or heat stress (Willits \& Peet, 1998). In many areas of the world, heat stress due to higher temperatures is a serious threat to crop production worldwide (Lorenzoni et al., 2001). Transient or constantly high temperatures cause a range of morpho-anatomical, physiological and biochemical changes in plants that affect plant growth and development and can result in a drastic reduction in economic output (Keswani, 2015; Wahid et al., 2007) (Figure 1). As plants lack the capability of locomotion as a means of responding to changes in their environment, they are exposed to various environmental stresses and must adapt to them in other ways. The most typical kind of stress plants receives from their surroundings is temperature stress. Each plant species has its own optimum temperature for growth, and its distribution is de- 


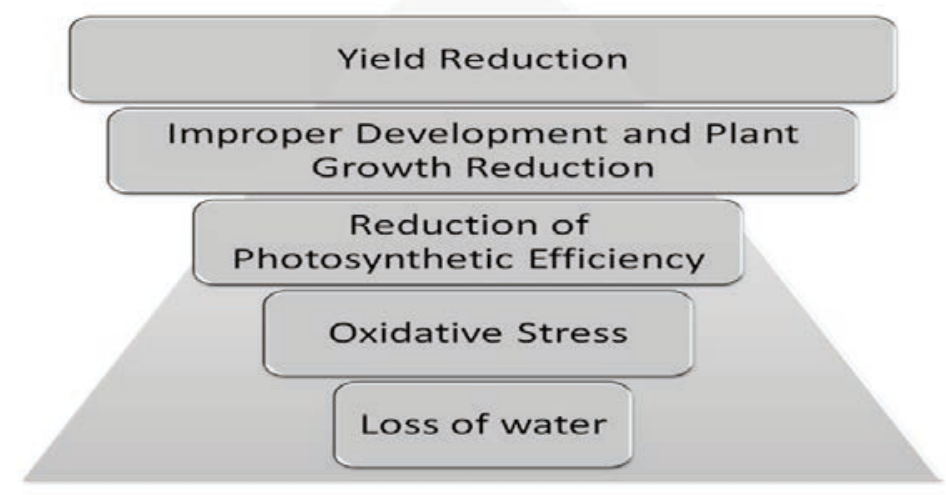

Figure 1: Correlation of heat stress with biochemical and physiological parameters of host

termined to a major extent by the temperature zone in which it can survive (Ram et al., 2018; Sasaki, 1997).

Severe cell injury and even cell death can occur in minutes at very high temperatures, which can be attributed to a catastrophic collapse of cellular organization (Schoffl et al., 1997). High temperature direct injuries include protein denaturation, aggregation, and increased membrane lipid fluidity. Indirect or slower heat injuries include chloroplast and mitochondrial inactivation of enzymes, protein synthesis inhibition, protein degradation, and membrane integrity loss (Singh et al., 2016; Singh et al., 2017).

At very high temperatures, severe cellular injury and even cell death may occur within minutes, which could be attributed to a catastrophic collapse of cellular organization (Schoffl et al., 1997). High temperature causes both direct and indirect or slower heat injuries. Direct injuries include protein aggregation, denaturation, and increased membrane fluidity whereas, indirect or slower heat injuries include enzymes inactivation in both chloroplast and mitochondria, protein degradation, inhibition of protein synthesis and loss of membrane integrity (Howarth, 2005). High temperatures can also cause considerable pre- and post-harvest damages, including scorching of leaves and twigs, sunburns on leaves, branches and stems, leaf senescence and abscission, shoot and root growth inhibition, fruit discoloration and damage, and reduced yield (Guilioni et al., 1997; Vollenweider \& Günthardt-Goerg, 2005).

\section{PRODUCTION OF ROS AND THEIR HEALTH IMPACT ON PLANT}

Oxygen supports the aerobic life of plants, provid- ing them with enormous energy benefits, but challenges them through endless ROS formation (Figure 2). However, certain environmental stresses or genetic defects cause ROS production to exceed the management capacity. In plants, ROS play two divergent roles: at lower concentrations, it acts as signaling molecules to activate defense responses under stress, while exacerbating damage to the cellular component at higher concentrations. If abiotic stress is imposed on the plant for a longer duration than, through enhanced ROS production, can pose a severe threat to cells by causing the lipids peroxidation, proteins oxidation, damage to nucleic acids, enzyme inhibition, programmed cell death (PCD) pathway activation and ultimately cell death (Mittler, 2002; Sharma \& Dubey, 2005). Oxidative stress is essentially a regulated process, and the equilibrium between ROS and anti-oxidative capacity determines the fate of the plant. The enhanced ROS production is, however, kept under tight control by versatile and cooperative ROS-scavenging antioxidant mechanisms that modulate intracellular ROS concentration (Apel \& Hirt, 2004). Oxygen activation or reduction results in reactive ROS including singlet oxygen $\left({ }^{1} \mathrm{O}_{2}\right)$, superoxide $\left(\mathrm{O}^{2 \cdot-}\right)$, hydrogen peroxide $\left(\mathrm{H}_{2} \mathrm{O}_{2}\right)$ and radical hydroxyl ( $\left.\mathrm{HO}^{*}\right)$. The imbalance between the production of ROS and its detoxification through enzymatic and nonenzymatic reactions causes oxidative stress. Photo-oxidative damage to DNA, proteins and lipids, and ultimately cell death occurs as a result of higher net ROS formation. ROS act as signaling molecules for development and growth, defense responses of pathogens such as systemic acquired resistance and hypersensitive reaction, production of the stress hormone, acclimation and programmed cell death (Singh et al., 2019b; Apel \& Hirt, 2004). The first step in the $\mathrm{O}_{2}$ reduction results in the formation of superoxide $\left(\mathrm{O}_{2}{ }^{--}\right)$or hydroperoxide $\left(\mathrm{HO}_{2}{ }_{2}\right)$ radicals. $\mathrm{O}_{2}{ }^{\cdot-}$ 


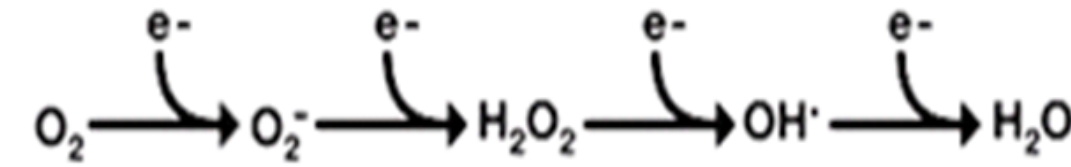 Oxyge Superoxid Hydrogen Hydroxyl wate n e anion peroxide radical r}

Figure 2: Production of ROS by a multistep reduction of molecular oxygen

is very unstable and has a short half-life of 2 to $4 \mathrm{~min}$. The second step leads to the formation of a relatively stable molecule hydrogen peroxide $\left(\mathrm{H}_{2} \mathrm{O}_{2}\right)$ with a half-life of $10 \mathrm{~min}$. $\mathrm{H}_{2} \mathrm{O}_{2}$ can migrate from the sites of synthesis to adjacent compartments and even neighboring cells due to longer half-life (Bienert et al., 2006). The oxidizing capacity of $\mathrm{O}_{2}^{\cdot-}$ and $\mathrm{H}_{2} \mathrm{O}_{2}$ makes them potentially harmful to the cell environment surrounding them. $\mathrm{O}_{2}{ }^{--}$may inactivate significant metabolic enzymes that contain $\mathrm{Fe}-\mathrm{S}$ clusters and alter catalytic activity (Halliwell, 2006; Van Breusegem et al., 2001). $\mathrm{HO}_{2}{ }_{2}$ (a protonated form of $\mathrm{O}_{2}{ }^{--}$) is mostly found in cellular acidic environments. $\mathrm{HO}^{\circ}$ may cross biological membranes and initiate oxidation of lipid by extraction of protons from polyunsaturated fatty acids. In most biological systems, the enzyme superoxide dismutase (SOD) rapidly converts $\mathrm{O}_{2}{ }^{--}$to $\mathrm{H}_{2} \mathrm{O}_{2}$. By oxidizing the thiol group of enzymes, $\mathrm{H}_{2} \mathrm{O}_{2}$ can inactivate them (Halliwell, 2006). $\mathrm{O}_{2}{ }^{--}$and $\mathrm{H}_{2} \mathrm{O}_{2}$ can cause more prominent destruction when interacting with metal ions during the so-called Haber-Weiss reaction to form the highly reactive hydroxyl radical (Kehrer, 2000).

$\mathrm{HO}^{*}$ can react virtually anything that comes into contact with and damages it (Halliwell, 2006). $\mathrm{HO}^{\circ}$ is highly reactive; cells do not have $\mathrm{HO}^{*}$ detoxification enzyme and are dependent on mechanisms that reduce $\mathrm{HO}^{\circ}$ production. These mechanisms include the elimination of $\mathrm{O}_{2}{ }^{--}$and $\mathrm{H}_{2} \mathrm{O}_{2}$ and/or metal ions sequestration that catalyze the Haber-Weiss reaction with metal-binding proteins, such as ferritins or metallothioneins (Hintze \& Theil, 2006).

\section{PLANT ORGANELLES INVOLVED IN ROS PRODUCTION}

Chloroplast, mitochondria, and peroxisome are organelles with a high oxidizing metabolic activity or an intense rate of electron flow and are the major source plant ROS production (Figure 3). Together with these organelles, peroxidases and amine oxidases present in cell walls and NADPH oxidase in the plasma membrane, often producing ROS in response to stress. Due to photosynthetic electron transport, oxygen is continuously produced inside the chloroplast and at the same time removed by reduction and assimilation (Keswani, 2015; Chawla et al., 2013; Shoeb et al., 2013; Tripathy \& Oelmüller, 2012).

An unavoidable leakage of electrons onto $\mathrm{O}_{2}$ from the electron transport activities of mitochondria, chloroplasts and plasma membranes or from a diversity of metabolic by-products in different cellular compartments can lead to the formation of ROS in plants (Keswani et al., 2016b; Sharma et al., 2012).

\subsection{CHLOROPLAST}

Different forms of ROS are generated from several locations in chloroplast. In chloroplasts, the main sources of ROS are electron transportation chains in Photosystem I (PSI) and Photosystem II (PSII). ROS production by these sources is enhanced in plants by limiting $\mathrm{CO}_{2}$ fixation conditions, such as drought, salt, and temperature stresses, as well as by combining these conditions with high-light stress. In case of ETC overload, because NADP supply decreases due to stress conditions, the electrons leak from ferredoxin to $\mathrm{O}_{2}$, reducing it to $\mathrm{O}_{2}{ }^{-}$ occurs in the case of overloading of the ETC (Elstner, 1991). This process is called the Mehler reaction.

\subsection{MITOCHONDRIA}

Mitochondria can produce ROS at multiple ETC sites. In mitochondria, the flavoprotein region of $\mathrm{NADH}$ dehydrogenase segment (complex I) of the respira-

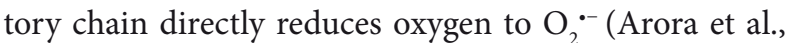
2002). In ETC, the primary ROS formed by a monovalent reduction is $\mathrm{O}_{2}^{--}$. It is quickly converted into the relatively stable and membrane-permeable $\mathrm{H}_{2} \mathrm{O}_{2}$ either by the MnSOD (a mitochondrial form of SOD) or APX. In Fenton reaction, $\mathrm{H}_{2} \mathrm{O}_{2}$ can be further converted to 


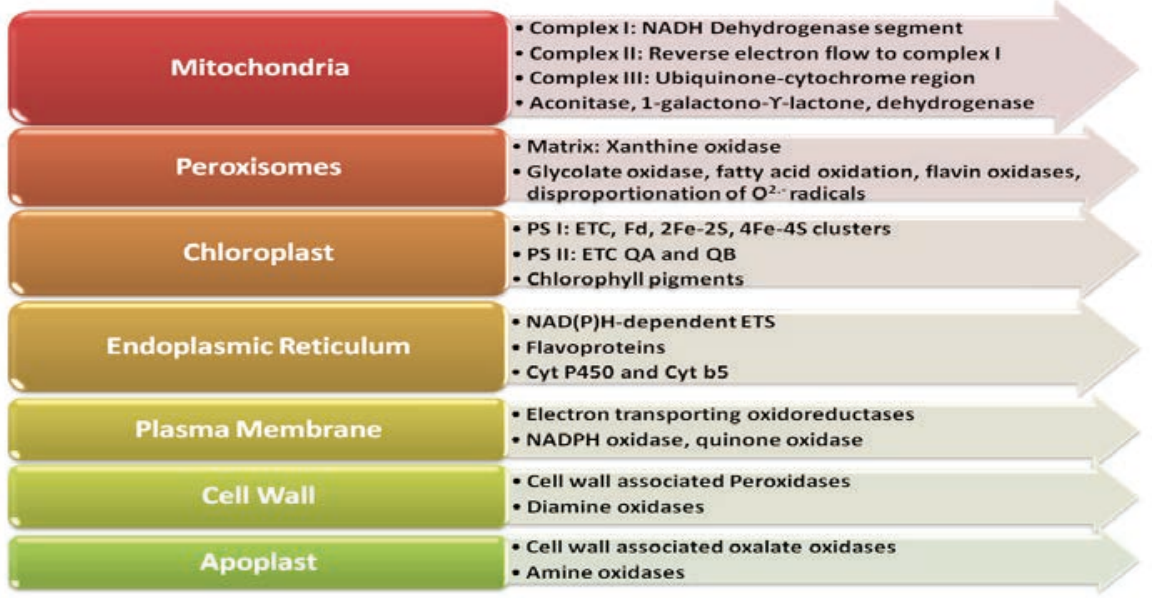

Figure 3: Plant organelles involved in ROS production

extremely active hydroxyl radical $\left(\mathrm{OH}^{*}\right)$ (Sharma et al., 2012).

\subsection{PEROXISOMES}

Peroxisomes are probably the major sites of intracellular $\mathrm{H}_{2} \mathrm{O}_{2}$ production, as a result of their essentially oxidative type of metabolism (Luis et al., 2006). The main metabolic processes responsible for the generation of $\mathrm{H}_{2} \mathrm{O}_{2}$ in different types of peroxisomes are the glycolate oxidase reaction, the fatty acid $\beta$-oxidation, the enzymatic reaction of flavin oxidases, and the disproportionation of $\mathrm{O}_{2}^{--}$radicals (Baker \& Graham, 2013). During photorespiration, the oxidation of glycolate by glycolate oxidase in peroxisomes accounts for the majority of $\mathrm{H}_{2} \mathrm{O}_{2}$ production (Noctor et al., 2002).

\subsection{PLASMA MEMBRANES}

The electron transporting oxido-reductases are ubiquitous at plasma membranes and lead to the generation of ROS at the plasma membrane (Kovačić, 2003). NADPH oxidase catalyzes the transfer of electrons from cytoplasmic NADPH to $\mathrm{O}_{2}$ to form $\mathrm{O}_{2}{ }^{\cdot-} \cdot \mathrm{O}_{2}{ }^{\cdot-}$ is dismutated to $\mathrm{H}_{2} \mathrm{O}_{2}$ either spontaneously or through SOD activity. It was proposed that $\mathrm{NADPH}$ oxidase play a key role in plant production and accumulation of ROS under stress conditions (Apel \& Hirt, 2004).

\section{ROS SIGNALLING IN PLANTS}

In plant cells, ROS are continuously produced as a consequence of aerobic metabolism in all the intracellular organelles, in particular in the chloroplast, mitochondria and peroxisomes (Bisen et al., 2015; Apel \& Hirt, 2004). The chloroplast is the main source of ROS in plants. Insufficient energy dissipation during photosynthesis can lead to the formation of a chlorophyll triplet state that can transfer its excitation energy onto $\mathrm{O}_{2}$ to make ${ }^{1} \mathrm{O}_{2}$ (Logan, 2008). $\mathrm{O}_{2}^{-{ }^{--}}$is produced by the photosynthetic electron transport chain (ETC) via the reduction of $\mathrm{O}_{2}$ (Mehler reaction) (Apel \& Hirt, 2004), which is subsequently converted to $\mathrm{H}_{2} \mathrm{O}_{2}$ by superoxide dismutase (Foyer \& Noctor, 2000). The photo-production of ROS is largely affected by physiological and environmental factors, including high light intensity and drought stress (Asada, 2006). Proline accumulation is a widespread phenomenon in higher plants in response to various environmental stresses and is demonstrated to be protective for plants under adverse conditions (Keswani et al., 2016a). Proline so accumulated is proposed to act as a compatible osmolyte, free radical scavenger, cell redox balancer, a potential inhibitor of programmed cell death (PCD), cytosolic pH buffer and stabilizer for subcellular structures during various stresses (Gill \& Tuteja, 2010; Kishor et al., 2005; Trovato et al., 2008). Under supra optimal temperature, free proline is known to accumulate in different crops (Rasheed et al., 2011). It is, therefore, considered to be a useful component for evaluating the degree of heat stress (Kuo et al., 1986).

\section{EXPLORING THE ROLE OF TRICHODER- $M A$ SPP. IN BIOTIC STRESS MANAGE- MENT}

The three-partite interactions involving plants, 
Trichoderma, phytopathogen and host has received less interest in contrast to the plant-antagonist, plant-pathogen or pathogen-antagonist interactions (Keswani et al., 2013; Singh et al., 2016; Singh et al., 2017). There are certain intricacies in studying a complex system even in vitro. Studies have shown some of the molecular or morphological features involved in plant-antagonist-pathogen interactions by application of gene reporter systems (Lu et al., 2004) and proteomics (Marra et al., 2006). The crosstalk during the three-partite interactions requires research that investigates the alteration in gene expression in each partner singly and afterward in all combinations. The main focus of the studies published so far in three way interaction has been related to molecular changes pathogen attack and/or plant response (Hammond-Kosack \& Parker, 2003; Jones \& Dangl, 2006). Various defense factors, signal molecules, virulence and avirulence factors have been identified in plant (Canovas et al., 2004; Ramonell \& Somerville, 2002), and in microbes (Kazemi-Pour et al., 2004; Smolka et al., 2003). However, the molecular bases of interaction systems that may generate beneficial effects on plant are mostly unknown. Furthermore, the influence of biocontrol agent in the plant and pathogen has not yet been studied by using proteomics, though this technique offers an effective tool to examine such biological processes (Keswani et al., 2013; Woo et al., 2006).

In order to analyze the differential protein produced during the three partite interactions between PlantTrichoderma-pathogen, (Singh et al., 2019a; Marra et al., 2006) investigated the interactions of Trichoderma, plant and different fungal pathogens by using proteomic techniques. During the three-way crosstalk, the alterations in each partner's proteomes were studied and the most attractive differential spots were analyzed via peptide mass finger-printing (PMF) (Bisen et al., 2016). Several proteins expressed differently have been found in the Trichoderma atroviride Karsten proteome during the three partite interactions with foliar pathogen Botrytis cinerea Pers.: Fr and bean leaves or with roots and the soil borne pathogen Rhizoctonia solani Kühn. Results demonstrated that in the three-partite interaction may be regulated by disease related factors and plant proteome-specific pathogenesis related proteins ( $\mathrm{PR}$ proteins). In addition to that, the plant responses to a pathogen attack are qualitatively and quantitatively affected by the presence of antagonist (Bisen et al., 2016). LC MS/MS previously identified a protein with PPIase activity in the Trichoderma harzianum Rifai proteome (Suárez et al., 2005). The in silico study of the data from plant-Trichoderma and plant-Botrytis interactions exposed many homologues to PR-proteins. Conserved domains such as Nucleotide Binding Sites (NBS), Leucine Rich Repeats (LRR) and
SGT1-specific domain (SGS) were found along with preserved Bet v I PR sequences and Barwin-protein families. For instance, thaumatin-like protein and tobacco PR-4 family with a Barwin domain involved in the Magnaporthe grisea (Hebert) Barr. plant defense response (Kim et al., 2004) were accumulated. Various proteins from the Trichoderma atroviride interaction proteome showed exciting similarities to those of ABC transporters and fungal hydrophobin. In the pathogen proteome, virulence factors such as cyclophilins were also regulated in the interaction with the antagonist and as well as with the plant. In Trichoderma-plant-pathogen in situ interaction, Gfp-tagged mutant strain Trichoderma atroviride was used to study the expression of the living producer (Lu et al., 2004). Specifically, incitement of Trichoderma genes encoding for diverse cell wall degrading enzymes in the vicinity of the pathogens Pithyum ultimum Trow and Rhizoctonia solani was observed by fluorescence microscopy. During the three partite interactions, purified colloidal chitin and the fungal pathogen activated the transformants and appeared to fluoresce during the early phases of contact. A direct visualization of the gene encoding the mycoparasitic expression in vivo is possible for the first time with this approach. The authors suggested that the induction of mycoparasitism involved compounds released by the host cell walls. In addition, T's endo-and exochitinase (nag1 and chit42) contribution of Trichoderma atroviride was also present in mycoparasitism other than basic host hyphae degradation.

\section{BIOPROSPECTING THE ROLE OF TRICHODERMA SPP, IN ALLEVIATION OF INDUCED OXIDATIVE STRESS}

Genus Trichoderma, competent of rhizosphere fungi are widely used in commercial formulations as biofertilizers and biopesticides due to multiple beneficial effects on plant growth and resistance to disease (Tucci et al., 2011). Various mechanisms of action, such as antibiotic production (Keswani et al., 2014; Vinale et al., 2008) or hydrolytic enzymes (Benítez et al., 2004) and nutrients competition (Elad, 2000) were associated with the antifungal properties of Trichoderma spp. Abiotic stress often limits the growth and productivity of major crop species, reducing yields under ideal growing conditions to less than half of that possible (Boyer, 1982) (Figure 4). Trichoderma spp. is also known to be able to induce biotic and abiotic stress resistance in plant and thereby encouraging plant growth (Harman et al., 2004). The ability of Trichoderma to alleviate abiotic stress is well known, although there is still a lack of specific knowledge of mechanisms that control multiple plant (Bisen et al., 


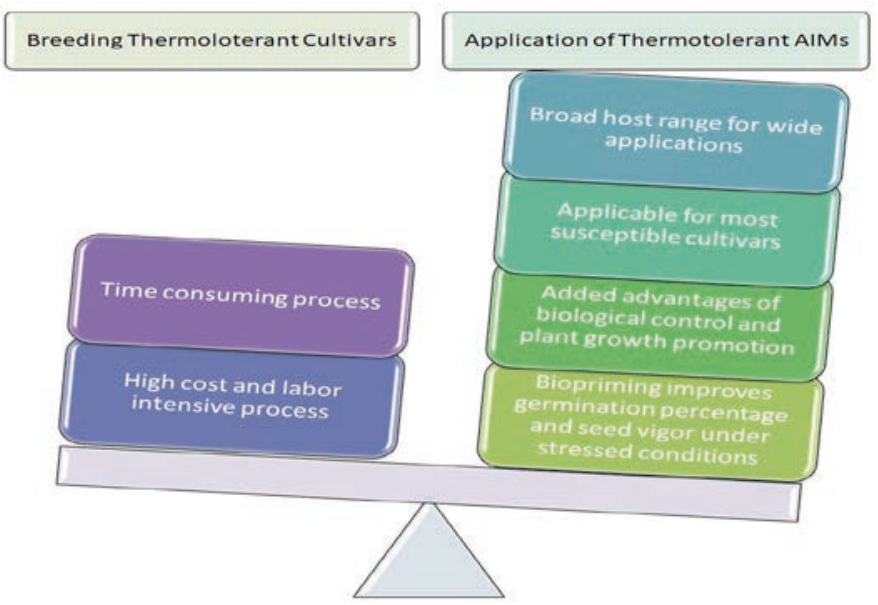

Figure 4: Relative advantages of using thermotolerant agriculturally important microrrganisms in comparison to breeding thermotolerant cultivars

2016; Chitara et al., 2017; Ram et al., 2018). Regardless of the stress condition, either osmotic, salinity, or suboptimal temperature the Trichoderma harzianum T22 treated seeds germinated rapidly and more uniformly than the untreated seeds (Mastouri et al., 2012). Some Trichoderma spp. are able to cope with extreme environments, facilitating their presence in diverse geographical regions, from Caribbean countries to Antarctica (Hermosa et al., 2012). T22 enhances the water tolerance of tomato seedlings by enhancing the antioxidant defense mechanism and enhancing ascorbate and glutathione-recycling enzyme activity (Mastouri et al., 2012).

Hence, these studies point to a possibility of employing thermotolerant strains of agriculturally important microorganisms in alleviation of heat stress in crops by relocating them in the rhizosphere for modulation of oxidative and defense network of the host, rendering it additional endurance to heat stress.

\section{ACKNOWLEDGEMENTS}

CK is grateful to Banaras Hindu University and Department of Science and Technology, New Delhi, India for providing financial support through DST-PURSE (5050) program.

\section{REFERENCES}

Acquaah, G. (2007). Principles of plant breeding and genetics. Malden, MA USA: Blackwell Publishing.

Apel, K., \& Hirt, H. (2004). Reactive oxygen species: metabolism, oxidative stress, and signal transduction. Annual Re- viewof Plant Biology, 55, 373-399. https://doi.org/10.1146/ annurev.arplant.55.031903.141701

Arora, A., Sairam, R., \& Srivastava, G. (2002). Oxidative stress and antioxidative system in plants. Current cience, 1227 1238.

Asada, K. (2006). Production and scavenging of reactive oxygen species in chloroplasts and their functions. Plant physiology, 141(2), 391-396. https://doi.org/10.1104/pp.106.082040

Baker, A., \& Graham, I. A. (2013). Plant peroxisomes: biochemistry, cell biology and biotechnological applications: Springer Science \& Business Media.

Bhatnagar-Mathur, P., Vadez, V., \& Sharma, K. K. (2008). Transgenic approaches for abiotic stress tolerance in plants: retrospect and prospects. Plant cell reports, 27(3), 411-424. https://doi.org/10.1007/s00299-007-0474-9

Bienert, G. P., Schjoerring, J. K., \& Jahn, T. P. (2006). Membrane transport of hydrogen peroxide. Biochimica et Biophysica Acta (BBA)-Biomembranes, 1758(8), 994-1003. https://doi. org/10.1016/j.bbamem.2006.02.015

Bisen, K., Keswani, C., Mishra, S., Saxena, A., Rakshit, A. \& Singh, H.B. (2015) Unrealized Potential of Seed Biopriming for Versatile Agriculture. In: Nutrient Use Efficiency: from Basics to Advances. Eds. A, Rakshit, H.B. Singh, A. Sen. Springer India, pp. 193-206. https://doi.org/10.1007/97881-322-2169-2_13

Bisen, K., Keswani, C., Patel, J.S., Sarma, B.K. \& Singh, H.B. (2016). Trichoderma spp.: Efficient Inducers of Systemic Resistance in Plants. In: Microbial-mediated Induced Systemic Resistance in Plants. Eds. Choudhary, D.K. and Verma, A. Springer Singapore, pp. 185-195. https://doi. org/10.1007/978-981-10-0388-2_12

Boyer, J. S. (1982). Plant productivity and environment. Science, 218(4571), 443-448. https://doi.org/10.1126/science.218.4571.443

Broecker, W. S. (1975). Climatic change: are we on the brink of a pronounced global warming? Science, 189(4201), 460-463. https://doi.org/10.1126/science.189.4201.460

Camejo, D., Rodríguez, P., Morales, M. A., Dell'Amico, J. M., 
Torrecillas, A., \& Alarcón, J. J. (2005). High temperature effects on photosynthetic activity of two tomato cultivars with different heat susceptibility. Journal of plant physiology, 162(3), 281-289. https://doi.org/10.1016/j. jplph.2004.07.014

Canovas, F. M., Dumas-Gaudot, E., Recorbet, G., Jorrin, J., Mock, H. P., \& Rossignol, M. (2004). Plant proteome analysis. Proteomics, 4(2), 285-298. https://doi.org/10.1002/ pmic. 200300602

Chawla, S., Jain, S., \& Jain, V. (2013). Salinity induced oxidative stress and antioxidant system in salt-tolerant and saltsensitive cultivars of rice (Oryza sativa L.). Journal of plant biochemistry and biotechnology, 22(1), 27-34. https://doi. org/10.1007/s13562-012-0107-4

Chitara, M.K., Keswani, C., Bisen, K., Singh, V., Singh, S.P., Sarma, B.K. \& Singh H.B. (2017). Improving Crop Performance under Heat Stress using Thermo tolerant Agriculturally Important Microorganisms. In: Advances in PGPR Research. Eds. Singh, H.B., Sarma, B.K., Keswani, C. CABI, Wallingford, UK, pp. 296-305. https://doi. org/10.1079/9781786390325.0296

Choudhury, S., Panda, P., Sahoo, L., \& Panda, S. K. (2013). Reactive oxygen species signaling in plants under abiotic stress. Plant signaling \& behavior, 8(4), e23681. https://doi. org/10.4161/psb.23681

Elad, Y. (2000). Biological control of foliar pathogens by means of Trichoderma harzianum and potential modes of action. Crop protection, 19(8-10), 709-714. https://doi.org/10.1016/ S0261-2194(00)00094-6

Elstner, E. F. (1991). Metabolisms of oxygen activation in different compartments of plant cells. Active Oxygen/Oxidative Stress and Plant Metabolism., 13-25.

Field, C.B. (Ed.) (2014). Climate change 2014-Impacts, adaptation and vulnerability: Regional aspects. Cambridge University Press, UK.

Foyer, C. H., \& Noctor, G. (2000). Tansley Review No. 112 Oxygen processing in photosynthesis: regulation and signalling. The New Phytologist, 146(3), 359-388. https://doi. org/10.1046/j.1469-8137.2000.00667.x

Gill, S. S., \& Tuteja, N. (2010). Reactive oxygen species and antioxidant machinery in abiotic stress tolerance in crop plants. Plant physiology and biochemistry, 48(12), 909-930. https:// doi.org/10.1016/j.plaphy.2010.08.016

Guilioni, L., Wery, J., \& Tardieu, F. (1997). Heat stress-induced abortion of buds and flowers in pea: is sensitivity linked to organ age or to relations between reproductive organs? Annals of Botany, 80(2), 159-168. https://doi.org/10.1006/ anbo. 1997.0425

Halliwell, B. (2006). Reactive species and antioxidants. Redox biology is a fundamental theme of aerobic life. Plant physiology, 141(2), 312-322. https://doi.org/10.1104/ pp.106.077073

Hammond-Kosack, K. E., \& Parker, J. E. (2003). Deciphering plant-pathogen communication: fresh perspectives for molecular resistance breeding. Current opinion in biotechnology, 14(2), 177-193. https://doi.org/10.1016/S09581669(03)00035-1

Harman, G. E., Howell, C. R., Viterbo, A., Chet, I., \& Lorito, M. (2004). Trichoderma species-opportunistic, avirulent plant symbionts. Nature reviews microbiology, 2(1), 43. https:// doi.org/10.1038/nrmicro797

Hasanuzzaman, M., Hossain, M. A., da Silva, J. A. T., \& Fujita, M. (2012). Plant response and tolerance to abiotic oxidative stress: antioxidant defense is a key factor. In: Crop stress and its management: Perspectives and strategies, Eds. B.: Venkateswarlu, A. K. Shanker, C. Shanker, M. Maheswari. Springer- Netherlands. p. 261-315. https://doi. org/10.1007/978-94-007-2220-0_8

Hermosa, R., Viterbo, A., Chet, I., \& Monte, E. (2012). Plantbeneficial effects of Trichoderma and of its genes. Microbiology, 158(1), 17-25. https://doi.org/10.1099/mic.0.0522740

Hintze, K., \& Theil, E. (2006). Cellular regulation and molecular interactions of the ferritins. Cellular and molecular life sciences, 63(5), 591. https://doi.org/10.1007/s00018-0055285-y

Howarth, C. (2005). Genetic improvements of tolerance to high temperature. In: Abiotic stresses-plant resistance through breeding and molecular approaches. Eds. M. Ashraf, P. J. C. Harris p. 277-300: The Haworth Press: New York.

Jones, J. D., \& Dangl, J. L. (2006). The plant immune system. Nature, 444(7117), 323. https://doi.org/10.1038/nature05286

Karl, T. R., Melillo, J. M., Peterson, T. C., \& Hassol, S. J. (2009). Global climate change impacts in the United States: Cambridge University Press.

Kazemi-Pour, N., Condemine, G., \& HugouvieuxCottePattat, N. (2004). The secretome of the plant pathogenic bacterium Erwinia chrysanthemi. Proteomics, 4(10), 3177-3186. https://doi.org/10.1002/pmic.200300814

Kehrer, J. P. (2000). The Haber-Weiss reaction and mechanisms of toxicity. Toxicology, 149(1), 43-50. https://doi. org/10.1016/S0300-483X(00)00231-6

Keswani, C., Singh, S.P. \& Singh, H.B. (2013). A Superstar in Biocontrol Enterprise: Trichoderma spp.. Biotech Today,3(2), 27-30. https://doi.org/10.5958/2322-0996.2014.00005.2

Keswani, C., Mishra, S., Sarma, B. K., Singh, S. P., \& Singh, H. B. (2014). Unraveling the efficient applications of secondary metabolites of various Trichoderma spp.. Applied microbiology and biotechnology, 98(2), 533-544. https://doi. org/10.1007/s00253-013-5344-5

Keswani, C.(2015). Proteomic studies of thermotolerant strain of Trichoderma spp.. Ph.D thesis. Banaras Hindu University, Varanasi, India, pp.126

Keswani, C., Bisen, K., Singh, V., Sarma, B.K. \& Singh H.B. (2016a) Formulation Technology of Biocontrol Agents: Present Status and Future Prospects. In: Bioformulations: for Sustainable Agriculture. Eds. Arora, N.K. Springer, New Delhi, India, pp. 35-52. https://doi.org/10.1007/978-81322-2779-3_2

Keswani, C., Bisen, K., Singh, S.P., Sarma, B.K. \& Singh H.B. (2016b) A proteomic approach to understand the tripartite interactions between plant-Trichoderma-pathogen: investigating the potential for efficient biological control. In: Plant, Soil and Microbes Vol. II: Mechanisms and Molecular Interactions. Eds. Hakeem K.R., Akhtar, M.S. Springer, USA, pp. 79-93. https://doi.org/10.1007/978-3-319-295732_5 
Unravelling efficient applications of agriculturally important microorganisms for alleviation of induced inter-cellular oxidative stress in crops

Keswani, C., (Eds.). Bioeconomy for Sustainable Development (2019). Springer-Nature, Singapore. P. 392

Kim, S. T., Kim, S. G., Hwang, D. H., Kang, S. Y., Kim, H. J., Lee, B. H., Kang, K. Y. (2004). Proteomic analysis of pathogenresponsive proteins from rice leaves induced by rice blast fungus, Magnaporthe grisea. Proteomics, 4(11), 3569-3578. https://doi.org/10.1002/pmic.200400999

Kishor, P. K., Sangam, S., Amrutha, R., Laxmi, P. S., Naidu, K., Rao, K., Sreenivasulu, N. (2005). Regulation of proline biosynthesis, degradation, uptake and transport in higher plants: its implications in plant growth and abiotic stress tolerance. Current science, 424-438.

Kovačić, P. (2003). Mechanism of drug and toxic actions of gossypol: focus on reactive oxygen species and electron transfer. Current medicinal chemistry, 10(24), 2711-2718. https:// doi.org/10.2174/0929867033456369

Kumar, G., Patel, J.S., Maharshi, A., Mukherjee, A., Keswani, C., Singh, S.P., Singh, H.B. \& Sarma, B.K. (2017). PGPR-Mediated Defence Responses in Plants under Biotic and Abiotic Stresses. In: Advances in PGPR Research. Eds. Singh, H.B., Sarma, B.K., Keswani, C. CABI, Wallingford, UK, pp. $427-$ 438.

Kuo, C., Chen, H., \& Ma, L. (1986). Effect of high temperature on proline content in tomato floral buds and leaves. Journal of the American Society for Horticultural Science. 111: 746750

Lobell, D. B., \& Burke, M. B. (2010). On the use of statistical models to predict crop yield responses to climate change. Agricultural and Forest Meteorology, 150(11), 1443-1452. https://doi.org/10.1016/j.agrformet.2010.07.008

Logan, B. A. (2008). 10 Reactive oxygen species and photosynthesis. Antioxidants and Reactive Oxygen Species in Plants, 250. https://doi.org/10.1002/9780470988565.ch10

Lorenzoni, I., Jordan, A., Favis-Mortlock, D., Viner, D., \& Hall, J. (2001). Developing sustainable practices to adapt to the impacts of climate change: a case study of agricultural systems in eastern England (UK). Regional Environmental Change, 2(3), 106-117.

Lu, Z., Tombolini, R., Woo, S., Zeilinger, S., Lorito, M., \& Jansson, J. K. (2004). In vivo study of Trichoderma-pathogenplant interactions, using constitutive and inducible green fluorescent protein reporter systems. Applied and Environmental Microbiology, 70(5), 3073-3081. https://doi. org/10.1128/AEM.70.5.3073-3081.2004

Luis, A., Sandalio, L. M., Corpas, F. J., Palma, J. M., \& Barroso, J. B. (2006). Reactive oxygen species and reactive nitrogen species in peroxisomes. Production, scavenging, and role in cell signaling. Plant physiology, 141(2), 330-335. https://doi. org/10.1104/pp.106.078204

Marra, R., Ambrosino, P., Carbone, V., Vinale, F., Woo, S. L., Ruocco, M., Soriente, I. (2006). Study of the three-way interaction between Trichoderma atroviride, plant and fungal pathogens by using a proteomic approach. Current genetics, 50(5), 307-321. https://doi.org/10.1007/s00294-006-0091-0

Mastouri, F., Björkman, T., \& Harman, G. E. (2012). Trichoderma harzianum enhances antioxidant defense of tomato seedlings and resistance to water deficit. Molecular plant-microbe interactions, 25(9), 1264-1271. https://doi. org/10.1094/MPMI-09-11-0240
Mertz, O., Mbow, C., Reenberg, A., \& Diouf, A. (2009). Farmers' perceptions of climate change and agricultural adaptation strategies in rural Sahel. Environmental management, 43(5), 804-816. https://doi.org/10.1007/s00267-008-9197-0

Mishra, S., Singh, A., Keswani, C., Saxena, A., Sarma, B.K. \& H.B. Singh. (2015). Harnessing plant-microbe interactions for enhanced protection against phytopathogens. In: Plant Microbe Symbiosis- Applied Facets. Ed. Arora, N.K. Springer, New Delhi, India, pp.111-125. https://doi.org/10.1007/97881-322-2068-8_5

Mittler, R. (2002). Oxidative stress, antioxidants and stress tolerance. Trends in plant science, 7(9), 405-410. https://doi. org/10.1016/S1360-1385(02)02312-9

NAAS (2013). Climate Resilient Agriculture in India. Policy Paper No. 65, National Academy of Agricultural Sciences, New Delhi, India. p. 20

NAAS 2017. Abiotic Stress Management with Focus on Drought, Flood and Hailstorm. Policy Paper No. $87 \mathrm{Na}$ tional Academy of Agricultural Sciences, New Delhi, India. p. 14

Noctor, G., Veljović-Jovanović, S., Driscoll, S., Novitskaya, L., \& Foyer, C. H. (2002). Drought and oxidative load in the leaves of $\mathrm{C} 3$ plants: a predominant role for photorespiration? Annals of Botany, 89(7), 841-850. https://doi. org/10.1093/aob/mcf096

Ram, R.M., Keswani, C., Bisen, K., Tripathi, R., Singh, S.P. \& Singh, H.B. (2018). Biocontrol Technology: Eco-Friendly Approaches for Sustainable Agriculture. In: Omics Technologies and Bio-Engineering: Towards Improving Quality of Life Volume II Microbial, Plant, Environmental and Industrial Technologies. Eds. Brah, D., Azevedo, V. Academic Press, London, U.K. pp. 177-190. https://doi.org/10.1016/ B978-0-12-815870-8.00010-3

Ramonell, K. M., \& Somerville, S. (2002). The genomics parade of defense responses: to infinity and beyond. Current opinion in plant biology, 5(4), 291-294. https://doi.org/10.1016/ S1369-5266(02)00266-2

Rasheed, R., Wahid, A., Farooq, M., Hussain, I., \& Basra, S. M. (2011). Role of proline and glycinebetaine pretreatments in improving heat tolerance of sprouting sugarcane (Saccharum sp.) buds. Plant growth regulation, 65(1), 35-45. https:// doi.org/10.1007/s10725-011-9572-3

Sasaki, T. (1997). Science of the rice plant (Genetics): Nobunkyo. Saseendran, S., Singh, K., Rathore, L., Singh, S., \& Sinha, S. (2000). Effects of climate change on rice production in the tropical humid climate of Kerala, India. Climatic Change, 44(4), 495-514. https://doi.org/10.1023/A:1005542414134

Schoffl, F., Prandl, R., Hinderhofer, K., \& Reindl, A. (1997). Molecular and applied aspects of the heat stress response and of common stress tolerance in plants. Acta Physiologiae Plantarum, 19(4). https://doi.org/10.1007/s11738-9970052-3

Sharma, P., \& Dubey, R. S. (2005). Drought induces oxidative stress and enhances the activities of antioxidant enzymes in growing rice seedlings. Plant growth regulation, 46(3), 209221. https://doi.org/10.1007/s10725-005-0002-2

Sharma, P., Jha, A. B., Dubey, R. S., \& Pessarakli, M. (2012). Reactive oxygen species, oxidative damage, and antioxidative de- 
fense mechanism in plants under stressful conditions. Journal of botany, 2012. https://doi.org/10.1155/2012/217037

Shoeb, M., Singh, B. R., Khan, J. A., Khan, W., Singh, B. N., Singh, H. B., \& Naqvi, A. H. (2013). ROS-dependent anticandidal activity of zinc oxide nanoparticles synthesized by using egg albumen as a biotemplate. Advances in Natural Sciences: Nanoscience and Nanotechnology, 4(3), 035015. https://doi.org/10.1088/2043-6262/4/3/035015

Singh, H.B, Sarma, B.K. \& Keswani, C. (Eds.) (2016). Agriculturally Important Microorganisms: Commercialization and Regulatory Requirements in Asia. Springer, Singapore. P. 336. https://doi.org/10.1007/978-981-10-2576-1

Singh, H.B., Keswani, C. \& Singh, S.P. (Eds.)(2019a). Intellectual Property Issues in Microbiology Springer-Nature, Singapore. P. 425. https://doi.org/10.1007/978-981-13-7466-1

Singh, H.B, Keswani, C., Reddy, M.S., Royano, E.S. \& GarcíaEstrada, C. (Eds.)(2019b). Secondary Metabolites of Plant Growth Promoting Rhizomicroorganisms: Discovery and Applications Springer-Nature, Singapore. P. 392. https://doi. org/10.1007/978-981-13-5862-3

Singh, V., Ray, S., Bisen, K., Keswani, C., Upadhyay, R. S., Sarma, B. K. \& Singh H. B. (2017) Unravelling the Dual Applications of Trichoderma spp. as Biopesticide and Biofertilizer. In: Advances in PGPR Research. Eds. Singh H. B., Sarma, B. K., Keswani, C. CABI, Wallingford, UK pp. 364-374.

Smolka, B., Lukac, R., Chydzinski, A., Plataniotis, K. N., \& Wojciechowski, W. (2003). Fast adaptive similarity based impulsive noise reduction filter. Real-Time Imaging, 9(4), 261-276. https://doi.org/10.1016/j.rti.2003.09.015

Suárez, M. B., Sanz, L., Chamorro, M. I., Rey, M., González, F. J., Llobell, A., \& Monte, E. (2005). Proteomic analysis of secreted proteins from Trichoderma harzianum: identification of a fungal cell wall-induced aspartic protease. Fungal Genetics and Biology, 42(11), 924-934. https://doi. org/10.1016/j.fgb.2005.08.002

Taiz, L., \& Zeiger, E. (2006). Plant physiology. 4th. Sinauer Associate, Sunderland, Mass., EUA.

Tripathy, B. C., \& Oelmüller, R. (2012). Reactive oxygen species generation and signaling in plants. Plant signaling \& behavior, 7(12), 1621-1633. https://doi.org/10.4161/psb.22455
Trovato, M., Mattioli, R., \& Costantino, P. (2008). Multiple roles of proline in plant stress tolerance and development. Rendiconti Lincei, 19(4), 325-346. https://doi.org/10.1007/ s12210-008-0022-8

Tucci, M., Ruocco, M., De Masi, L., De Palma, M., \& Lorito, M. (2011). The beneficial effect of Trichoderma spp. on tomato is modulated by the plant genotype. Molecular Plant Pathology, 12(4), 341-354. https://doi.org/10.1111/j.13643703.2010.00674.x

Van Breusegem, F., Vranová, E., Dat, J. F., \& Inzé, D. (2001). The role of active oxygen species in plant signal transduction. Plant Science, 161(3), 405-414. https://doi.org/10.1016/ S0168-9452(01)00452-6

Vinale, F., Sivasithamparam, K., Ghisalberti, E. L., Marra, R., Woo, S. L., \& Lorito, M. (2008). Trichoderma-plant-pathogen interactions. Soil Biology and Biochemistry, 40(1), 1-10. https://doi.org/10.1016/j.soilbio.2007.07.002

Vollenweider, P., \& Günthardt-Goerg, M. S. (2005). Diagnosis of abiotic and biotic stress factors using the visible symptoms in foliage. Environmental Pollution, 137(3), 455-465. https://doi.org/10.1016/j.envpol.2005.01.032

Wahid, A., Gelani, S., Ashraf, M., \& Foolad, M. R. (2007). Heat tolerance in plants: an overview. Environmental and experimental botany, 61(3), 199-223. https://doi.org/10.1016/j. envexpbot.2007.05.011

Wang, W., Vinocur, B., Shoseyov, O., \& Altman, A. (2004). Role of plant heat-shock proteins and molecular chaperones in the abiotic stress response. Trends in plant science, 9(5), 244-252. https://doi.org/10.1016/j.tplants.2004.03.006

Wang, Y., Mopper, S., \& Hasenstein, K. H. (2001). Effects of salinity on endogenous ABA, IAA, JA, and SA in Iris hexagona. Journal of chemical ecology, 27(2), 327-342. https:// doi.org/10.1023/A:1005632506230

Willits, D., \& Peet, M. (1998). The effect of night temperature on greenhouse grown tomato yields in warm climates. Agricultural and Forest Meteorology, 92(3), 191-202. https://doi. org/10.1016/S0168-1923(98)00089-6 